\title{
Community nursing in Belgium, Germany and the Netherlands
}

Jouke van der $\mathrm{Zee} \mathrm{PhD}$

Director, Netherlands Institute of Primary Health Care, Utrecht, and Charr of Primary

Health Care Research, Department of Medical Sociology, University of Lumburg.

Maastricht

Klarieke Kramer MA RN

Assistant Researcher, Department of Nursing and Carıng Research, Netherlands

Institute of Primary Health Care, Utrecht

Anneke Derksen MA RN

Former Student in Nursing Sciences, University of Limburg Maastncht

Ada Kerkstra PhD

Senıor Research Fellow, Department of Nursing and Caring Research, Netherlands

Instıtute of Primary Health Care, Utrecht

and F C J Stevens $\mathrm{PhD}$

Associate Professor, Department of Medical Sociology, University of Limburg,

Maastricht, The Netherlands

VAN DER ZEE J , KRAMER K, DERKSEN A , KERKSTRA A \& STEVENS F C J

(1994) Journal of Advanced Nursing 20, 791-801

Community nursing in Belgium, Germany and the Netherlands

This paper contains a comparative study on community nursing in the

Netherlands, Belgium and Germany, carried out in the region around

Maastricht, where the borders of the three countries meet The well-known

problem of comparative studies (the incomparability of concepts and data) has

been solved by using the same measuring instruments in the three countries

The comparison between the countries was on three aspects the level of care dependency of the patients, the type and number of services provided and the nurses' job interpretation and job satisfaction During 1 week in June or September 1991, 89 community nurses made records of all their home visits and nursing activities In total the community nurses paid 5165 home visits to provide care to 1796 patients The results indicate that both the level of care dependency of the patients as well as the type of care provided differs between the three countries Belgian community nurses have the highest number of patients with a high level of care dependency Curative services like technical nursing care and domestic care are most frequently provided by the German and Belgian community nurses Informing, educating and supporting care is most frequently provided by the Dutch community nurses The German community nurses spend less time on administration activities With respect to job 
interpretation and job satısfaction the following results were found The Dutch community nurses mentioned in their job interpretation many more preventive tasks, whereas the German community nurses more often mentioned domestic tasks Concerning the hygienic and technical tasks, no significant differences were found between the three countries Finally, job satisfaction is lowest in the Netherlands Dutch community nurses are less satisfied with the work organization and the possibilities of autonomy and professionalization than the German and Belgian community nurses

\section{INTRODUCTION}

International comparison of health care systems is both fascinatıng and complicated Financial and legal regulations determine concepts in different ways, even when terms themselves do not indicate differences The term 'community nursing' imples both home nursing and wellbaby care provided by the same person in one country (the Netherlands) while in other countries (Belgium, Germany, United Kıngdom) these services are organizationally separated So, one can never be sure, confronted with comparative studies, whether results found are due to differences in concepts, definitions or administrative peculianties of routınely available statıstics, or reflect real differences

The solution to this problem is the use of similar and comparable measurement instruments, an approach followed in this study In the area around Maastricht, where the borders of Belgium, Germany and the Netherlands meet and offer excellent logistic opportunities for comparative studies, community nurses have provided information about patient charactenstics, service provision and job interpretation/satısfaction with the and of standardized measuring instruments

This paper contains the results of this study and has been structured around the following research question

'To what extent can differences in the utilization and provision of community nursing services be derived from characteristics of the health care and social security system in a situation where comparable measuring instruments have been used?'

Before we can specify and answer this question we need to give an overview of the general features of community nursing in Belgium, Germany and the Netherlands and what is known from previous studies From this overview expectations and specific research questions can be derived

\section{COMMUNITY NURSING IN BELGIUM, GERMANY AND THE NETHERLANDS}

The scheme shown in Table 1 contains the essential characteristics of community and home nursing in the countries studied The categories (financial and legal conditions, supply/provider characteristics, demand/ consumer charactenstics) were borrowed from the Canadian economist Robert Evans (1981) who provides a systematic framework for the description of health care systems

\section{Legislation}

One of the most striking differences in legislation concerns the obligation for children to support their indigent parents In the Netherlands this obligation was abolished with the introduction of the 'Algemene Bijstandswet' (General Support Act) in 1965 providing the entitlement to financial support from the local government in case of indigence For the indigent elderly this support usually includes the payments required for a place in a home for the aged In the other two countries this obligation still exists, although in practice many exceptions mitigate the principle

The considerable differences in the proportion of elderly people living in institutions like homes for the aged and nursing homes in the Netherlands compared with the other two countries is partly due to this basic difference in legislation Another strikung feature in legislation regards the dependency of the medical professions no authorization by a physician is needed for the use of community nursing services in the Netherlands, physician authorization is needed for all services in Germany, and a muxed system exists in Belgium (authorization for technical services like injections and free access for general nursing services for heavily dependent persons) These differences shape the professional content of the nurses' work

\section{Financing}

Differences can also be found in financing home nursing organizations, in the Netherlands this is by a budget partly based on the proportion of persons over 70 years and some other indicators of a region, in Belgium by a mixed system of payment per item of service and per diem remuneration, and in Germany by a complete fee-for-service system

Germany differs from the other countries in the fact that home help and home nursing have been integrated in many cases Both services are often provided by one single Sozialstation (social station) In Belgium these two services are completely separated In the Netherlands there 
Table 1 Essentual characteristics of community and home nursing in the countnes studied (situation in 1990/91)

\section{Essential}

characteristics

Belgium

Financing/insurance

(a) General

(b) Remuneration of organization personnel

Legal conditions

(a) General

(b) Vocational

(c) Relationship with medical profession

Supply

(a) Type of organization

(b) Type of services provided by organization

(c) Type of care provided by personnel

Demand
(a) Populatıon over 65

in Euregion

Population over 75

in Euregion

(b) Population

permanently

residing in

institutions

(c) Life expectancy at birth

(d) Age adjusted death rate (direct standardization)t
Part of public health insurance $25 \%$ out of pocket payment, but not for widows, orphans, the disabled and pensioners

Technical services per item of service

Care-dependent patients per diem depending on seventy of case

Monthly salary (mostly part-tıme employment) for employees' home care organization Independent nurses are paid directly by insurances

Obligation for children to maintain parents if indigent

Title 'nurse' protected

For severely care-dependent patients direct access For injections and technical interventions authorization from physicians needed

White/Yellow Cross-nationwide organization for home nursing, plus independent nurses in private practices

Home nursing

Personal care, technical nursing procedures and psychosocial activities
$89 \%$
$34 \%$
$51 \%$
72 (men) 79 (women)
107

Part of public health insurance (60\%) plus federal or state taxes private health insurance, umbrella organizations and out of pocket payment

Governmental subsıdy dependıng on the number and qualificatıons of personnel Fee for service payment by insurance companies

A fixed monthly salary or payment on an hourly basis

Obligation for children to maintain parents if indigent

No protection of title 'nurse' All home nursing requires authorization by physician

'Plllarized' welfare organızation (Roman Catholic, Protestant, Socıalist)

Home nursing and home help (in many cases)

Helping the patient with basic needs, more technical nursing activities and home help

$\begin{array}{ll}142 \% & 107 \% \\ 59 \% & 40 \% \\ 45 \% & 77 \%\end{array}$

73 (men) $^{*}$

79 (women) $^{*}$

105
Since 1981 part of (public) catastrophic illness insurance plus membership foe of appr 20 ECUs per vear

Organızation receives budget dependent on percentage of those over 70 and in region, and some other indicators, plus membership fees, plus budget for well-baby care

Salary dependent on qualification (full nurse-nurse auxiliary)
74 (men)

80 (women)

No obligation for children to maintain parents since 1965 (General Support Act)

Title 'nurse' protected

Directly accessible no physician authorization needed

Single national home care organization plus limited number of private nurses

Home nursing and well-baby care

Mother and child care in child health clinic sessions and nursing activities during home visits

92

\section{* Figures from 1989}

+ Figures from 1985

Sources Phılıpsen (1985), van de Ven (1988), Derksen (1991), Nı)kamp et al (1991), Verhel) \& Kerkstra (1992), Boerma et al (1993) 
is a growing tendency to merge the governing boards of home help and home nursıng organizations, but, certainly in 1991, the practical integration of both services was exceptional

Traditionally Dutch community nurses provide both well-baby care and home nursing services, in both other countries (as in the United Kingdom) these preventive well-baby services are provided by a different organization

In Germany and Belgium home care is not provided by one single organization (like in the Netherlands) but by different denominations (Roman Catholic, Protestant and Socıalıst in Germany, Roman Catholic and Socialıst in Belgium) A comparable situation existed in the Netherlands untll the mid-seventies (with one Roman Catholic, one general and one Protestant organization) untul all organizations merged into the National Cross Association

\section{EXPECTATIONS}

From these general differences a set of expectations can be derived These can be divided into expectations regarding the severity of the patient's situation (the 'level of care dependency'), the actual provision of services and the nurse's job interpretation and job satisfaction

\section{Expectations regarding the level of care dependency}

The higher proportion of institutionalized elderly people in the Netherlands might lead to a relatively lighter case load in the Netherlands compared with the other two countries, especially because community nurses do not provide services in homes for the aged in the Netherlands

The living situation of elderly people will also be different, we expect more elderly people to be living with their children in Belgium and Germany than in the Netherlands

\section{Expectations regarding the provision of services by community nurses}

The financing by budget of the Dutch home nursing associations and the reluctance of Dutch home nurses to comply with medical supervision will most probably lead to a lower number of technical services performed by Dutch community nurses

Direct access of home nursing in the Netherlands and an increasing degree of medical authorization in the Netherlands, compared with Belgium and Germany, will lead to the Netherlands having the lowest proportion of patients arriving via the medical profession and the highest number of durect arrivals Germany will show the opposite pattern and Belgium is expected to occupy the position in between
The integration of home help and home nursing in Germany will probably lead to a less strict separation of home help and home nursing activities in Germany compared with the other two countries This will show both in the actual services and in the job interpretation

The greater dispersion of the German Sozialstationen due to the different denominations might lead to higher travel times for the German nurses

\section{Expectatıons regarding job unterpretation and job satisfaction}

It was already predicted that German community nurses would be more likely to describe domestic services as part of their job Finally, we predict that Dutch community nurses will have a higher job satisfaction due to their greater independence (especially from the medical profession)

\section{Previous studies}

Some of these expectations are (partially) supported by previous studies Kerkstra \& Voskuilen (1992) compared the work-profiles of Dutch and Belgian community nurses based on a secondary analysis of a Dutch nationwide survey of community nurses' activities (Vorst Thyssen et al 1990) and two Belgian studies by Geys \& Van Loon $(1989,1990)$ who used routinely avalable data on Belgian community nurses' services They found that Belgian nurses provided more curative and technical services than their Dutch colleagues and less preventive and supportıve care The authors state however that the differences found could be due to the differences in data sources, Belgian data consisting of administrative and financially relevant items and Dutch data stemming from self-recorded survey registration

\section{Further specufication of the research questions}

After formulating the expectations, the research questions can be specified as follows

1 To what extent can differences between community nursing in Belgium, Germany and the Netherlands in (a) patients' level of care dependency, (b) services provided by community nurses, and (c) job interpretation and job satusfaction, be derived from characteristics of the health care and social security system according to the expectations formulated in the introduction?

2 Will differences found in previous studies (especially between community nursing in the Netherlands and Belgium) also be found if comparable and similar measuring instruments are used? 


\section{THE STUDY}

The study was carned out in the 'Euregion', the area where the borders of Germany, Belgium and the Netherlands meet

Several home nursing organizations (in Maastricht and the surrounding area, in the Dutch speaking Belgian province of Limburg and in several Sozıalstationen of different denominations in the region of Aachen/Stolberg) were approached for cooperation The organizations passed this request to nursing units who participated on a voluntary base A target of approxımately 30 nurses per country was set in order to allow for some crude testing of differences (by ch1-square or $t$-tests)

The nurses were asked during 1 week in late summer and early autumn in 1991

1 to assess (at the first contact) the physical and mental health status and living conditions of all home nursing patients during this week (for the Dutch nurses this implied the exclusion of well-baby care),

2 to record their activities during all contacts with these patients, and

3 to complete a questionnaire on job interpretation and job satusfaction

The basic characteristics of the sample are shown in Table 2 No male nurses were employed in Belgium The age of the nurses did not differ significantly (due to the high standard deviation in Germanyl Employment did differ nurses in Germany were predominantly full-tıme employed, in the Netherlands approxumately $60 \%$ had a full-tıme job, but in Belgium most nurses worked 20-28 hours

The size of the teams varied considerably, in Germany and the Netherlands it was between 10 and 15 persons and in Belgium the average was 53 persons The Belgian home nursing organization with large teams of part-time nurses differs strongly from the other two countries

\section{Measurement instruments}

The three core concepts the condition of the patients (the level of care-dependency), the services provided and the nurses' job interpretation and satisfaction have been elaborated as follows

\section{Patient's condition}

The condition of the patient has been operationalized by taking the standard condition assessment scale used (since Spring 1991) by Belgian community nurses to assess the degree of care dependency of their chents The instrument consists of the original Katz ADL-scale (Katz et al 1963) and has been extended by the White/Yellow Cross Organization to include mental condition (restlessness/ nervousness and memory problems), housing and living conditions and the avalability of informal care, this all resultıng in a score of which the physical condition scale (the Katz-scale) has a direct relationship with the per diem reimbursement This ADL-scale has a six-point range, the highest scores are obtained for incontinent patients or patients who cannot eat or drink without help For scores of 0-2 no per diem reimbursement is applicable (fee for service only and medical authorization required, with a maximum), for scores of 3 and 4 the lowest reimbursement category applies (1991, BF 450, ECU 10,65) and for scores of 5 and 6 the highest category (1991, BF 750, ECU 17,76) applies

The mental condition scale consists of two elements (0-3 rating scale) an estımate of time and place onentation and/or assessment of the degree of restlessness Finally, the avalability of informal care (under the same roof or elsewhere) and the housing quality (bathing and warm water facilities, 0-2 rating) complete the list

As the Belgian scales were avallable in Dutch (including instructions) no translation problems existed for the Dutch situation, in order to be applicable in Germany a translation took place Dutch and German nurses were instructed by the investigator who did the study as a master's thesis in nursing science (Derksen 1991) The Belgian nurses were already familiar with its use

\section{Services provided}

The community nursing care provided was measured using the patient contact registration form developed by
Table 2 Sample characteristics and basic information

\begin{tabular}{lccrr}
\hline & Bel & Ger & Net & Total \\
\hline Number of nurses & 30 & 22 & 35 & 87 \\
(of which male nurses) & 0 & 4 & 5 & 9 \\
Average age & 30 & 36 & 32 & 324 \\
Number of years job expenence & 7 & 7 & 6 & \\
Number of patient profiles (/wk) & 729 & 361 & 706 & 1796 \\
Number of home visits (/wk) & 2178 & 1569 & 1416 & 5163 \\
Average team size & $50-55$ & $13-14$ & $11-12$ & \\
Number of working hours (/wk) & 27 & 38 & 34 & 328 \\
\hline
\end{tabular}


Kerkstra \& Vorst-Thijssen (1991) for a nationwide survey on community nursing in the Netherlands For each home visit a form was completed containıng information regarding the patient's name, sex, age, living situation, diagnosis, the motives for visiting the patient at home, whether or not the patient is receiving informal care, the time of arnval and departure of the community nurse and the type of care provided A detaled list of activities was divided into the following main headings

1 Hygienic care help with washing, dressing and the lavatory, bathing the patient, and care of harr, nalls and feet

2 Self-care stimulation of the patient's self-care

3 Domestic care preparing food and drinks, and cleaning the bathroom, etc

4 Technical care care of pressure sores and wounds, stomacare, catherization, etc

5 Injections all sorts of injections administered during a home visit

6 Moral support listening, empathic understanding and advising

7 Family support giving advice to relatives, giving instructions on nursing care, and discussing the workload of the informal caregivers

8 Health education giving information to the patient regarding the nature of the illness, the use of medicines, the possibility of self-care and informal care, auxiliary apparatus and adaptation of the house

9 Observation observation of new physical symptoms, and mental or social problems

10 Administration recording information about the patient and the care given to the patient on the patient's card

In order to explore the dimensionality of these activities a factor analysis (principal components with orthogonal varimax rotation) was performed (Table 3)

The three-factor solution, accounting for $624 \%$ of the variance is presented in Table 3 The first factor, containing health education, psychosocial care, the support of informal care and observation can be labelled as 'care' It refers to the personal, general and affective aspects of treatment, generally and for a long period considered as crucial for therapeutic effectiveness (Carkhuff 1969, White 1988)

The second factor contains hygienic personal care, st1mulatıng self-care, domestic care and techmical activities, while injections load negatively This can be interpreted as a typical instrumental factor to be labelled as 'cure', although the negative loading of injections justufies exclusion of this variable from the actual factor construction The indicator for homogeneity (Cronbach's alpha) is much better ( 073$)$ when injections are excluded than when included (0 47) Both dimensions form the core elements of health care, both in the medical sector and in nursing Finally, administrative procedures form a category of their own
Table 3 Factor analysis of aggregated data on service provision by communty nurses $(n=87)$ (Principal component analysis with varimax rotation, three factor solution)

\begin{tabular}{lccc}
\hline Type of care & $\begin{array}{l}\text { Factor 1 } \\
\text { Care }\end{array}$ & $\begin{array}{l}\text { Factor 2 } \\
\text { Cure }\end{array}$ & $\begin{array}{l}\text { Factor 3 } \\
\text { Administration }\end{array}$ \\
\hline Health education & 090 & 018 & 017 \\
Psychosocial care & 089 & 007 & 019 \\
Support informal care & 075 & 004 & 018 \\
Observation & 066 & 017 & 017 \\
Hygienic care & 004 & 090 & -001 \\
Domestic activities & -005 & 078 & 022 \\
Technical nursing care & 038 & 061 & -034 \\
Stimulating self-care & 036 & 050 & 014 \\
Injections & -020 & -048 & -016 \\
Administration & 016 & 010 & 089 \\
Explained variance & $364 \%$ & $168 \%$ & $110 \%$ \\
Cronbach's alpha & 082 & 047 & na \\
& & $073 *$ & \\
\hline
\end{tabular}

* Without injections

\section{Job interpretation and job satisfaction}

The term 'job interpretation' refers to the set of tasks that nurses consider to form their job As no valıdated questionnare on this particular subject was avallable, an ad hoc scale was constructed containing 10 separate tasks (Table 4), derived from the literature on home nursing (Vorst-Thyssen et al 1990, Verhelj \& Kerkstra 1992) and some common sense The nurses had to judge whether they considered the specific tasks as part of their jobs (on a three-point scale) In order to reduce the number of dimensions the items were subjected to a similar factor analysis as presented in Table 3 , the results are presented in Table 4

The factors 'preventive/supportive care', 'domestic care' and 'curative/technical care' are clearly interpretable The first and the third factors are simular to the care and cure factors in the actual activities, domestic care appearing separately This is most probably due to the fact that in the questionnaure more attention was pard to the subject than in real hife Scores were obtained by adding the items, the alpha for the preventive/supportive scale was 053 (and for the other two dimensions respectively 065 and 056 )

No avalable scale could be found to measure job satısfaction of community nurses So a scale was derived from Stevens et al (1992), who studied the tension between professional responsibility and independence and the organizational requirements of medical specialists in general and university hospitals

Factor analysis (Table 5) yrelded three easily interpretable factors, satısfaction with the organization, satisfaction 
Table 4 Factor analysis of nurses' job interpretation ( $n=87$ ), principal component analysis with orthogonal varimax rotation three factor solution

Table 5 Factor analysis of nurses' job satısfaction ( $n=$ 87), principal component analysis with orthogonal varumax rotation ( 3 factor solution)

\begin{tabular}{lccc}
\hline & $\begin{array}{l}\text { Factor 1 } \\
\text { Preventive/ } \\
\text { supportive }\end{array}$ & $\begin{array}{l}\text { Factor } 2 \\
\text { Domestic care }\end{array}$ & $\begin{array}{l}\text { Factor 3 } \\
\text { Technical care }\end{array}$ \\
\hline Type of tasks & 070 & 004 & 004 \\
\hline Coordination of care & 069 & -014 & 004 \\
Health education & 059 & -017 & -026 \\
Preventive home visits & 054 & 038 & 021 \\
Psychosocial care & 046 & 000 & -014 \\
Improving self-care & 008 & 085 & 012 \\
Domestic care combined with & 005 & 081 & -021 \\
nursing activities & 002 & 005 & 087 \\
Domestic care & 013 & 010 & 079 \\
Technical nursing care & $211 \%$ & $175 \%$ & $170 \%$ \\
Hygienic/personal care & 053 & 065 & 056 \\
Explained variance & & & \\
Gronbach's alpha & & &
\end{tabular}

\begin{tabular}{|c|c|c|c|}
\hline Job aspects & $\begin{array}{l}\text { Factor } 1 \\
\text { Organization } \\
\text { conditions }\end{array}$ & $\begin{array}{l}\text { Factor } 2 \\
\text { Professional } \\
\text { conditions }\end{array}$ & $\begin{array}{l}\text { Factor } 3 \\
\text { Social } \\
\text { conditions }\end{array}$ \\
\hline Homecare organızation as a whole & 071 & 041 & 007 \\
\hline Organızation of night and weekend duties & 063 & 026 & 029 \\
\hline Career possibilities & 060 & 040 & 017 \\
\hline Income & 058 & 004 & 036 \\
\hline Time for your work & 057 & 018 & 021 \\
\hline Workıng conditions & 051 & 015 & 004 \\
\hline Contacts with other disciplines & -048 & 031 & -008 \\
\hline Opportunity for high quality care & 007 & 072 & 009 \\
\hline Continuous education/training with practice & 016 & 066 & 001 \\
\hline Autonomy in patients' care & 006 & 066 & 008 \\
\hline Supervision management & 023 & 053 & 028 \\
\hline Opportunity for independent working & 004 & 053 & 046 \\
\hline Opportunity for postgraduate education & 009 & 043 & 004 \\
\hline Relations with colleagues & 010 & 011 & 068 \\
\hline Contact with other comm nurses & 022 & 014 & 057 \\
\hline Appreciation by outsıders & 040 & 014 & 057 \\
\hline Appreciation by patients & 032 & 022 & 045 \\
\hline Explained variance & $259 \%$ & $98 \%$ & $88 \%$ \\
\hline \multirow[t]{2}{*}{ Cronbach's alpha } & 068 & 068 & 049 \\
\hline & $077^{*}$ & & \\
\hline
\end{tabular}

* Without contacts with other disciplines with professional conditions, and satisfaction with the social aspects of the job Cronbach's alpha's were respectIvely 068,068 and 049

\section{RESULTS}

In Table 6 some background characteristics of the patients are presented German patients were the oldest and Dutch patients the youngest, there was an average difference of
5 years between Germany and the Netherlands The age differences also have an indirect effect (there are more older women than men) on the sex distribution $35 \%$ of patients were male in the Netherlands and $26 \%$ in Germany In Belgium the lowest percentage of persons were living alone, $35 \%$ against $44 \%$ and $42 \%$ respectively in Germany and the Netherlands The avallability of informal care does not differ significantly between the countries but there are differences in the type of informal care, in 
Table 6 Basic charactenstics of patients under treatment

\begin{tabular}{|c|c|c|c|c|}
\hline & $\begin{array}{l}\text { Bel } \\
(n=729)\end{array}$ & $\begin{array}{l}\text { Ger } \\
(n=361)\end{array}$ & $\begin{array}{l}\text { Net } \\
(n=706)\end{array}$ & $\begin{array}{l}\text { Significant } \\
\text { differences }\end{array}$ \\
\hline Average age & 744 & 776 & 728 & Ger vs Bel, Net * * \\
\hline$\%$ under 65 years & 20 & 11 & 21 & Ger vs Bel , Net.* \\
\hline$\%$ over 75 years & 55 & 67 & 47 & Bel vs Ger vs Net * \\
\hline$\%$ male patients & 30 & 26 & 35 & Bel vs Ger vs Net * \\
\hline$\%$ living alone & 35 & 44 & 42 & Bel vs Ger, Net * \\
\hline$\%$ living with partner & 40 & 31 & 41 & Ger vs Bel, Net * \\
\hline \% living with children or other family & 32 & 35 & 25 & Net vs Bel, Ger * \\
\hline \multicolumn{5}{|l|}{ Type of referral to community care } \\
\hline Self-referral (\%) & 43 & 47 & 51 & Bel vs Ger vs Net * \\
\hline General practitioners (\%) & 30 & 50 & 12 & Bel vs Ger vs Net * \\
\hline Hospital/nursing home (\%) & 11 & 13 & 30 & Net vs Bel, Ger * \\
\hline
\end{tabular}

* Differences tested by chi-square, $P<005$

* * Differences tested by $t$-test, $P<005$ the Netherlands $25 \%$ of patients lived with children or other family, in Belgium 32\% and in Germany 35\% The difference between the Netherlands and the two other countries is significant

The number of patients referred by general practitioners 1s, as predicted, highest in Germany ( $50 \%$ ), followed by Belgium (30\%) and the Netherlands (12\%) It was not predicted that the Dutch nurses had almost three tumes as many patients referred from institutional care

The level of care dependency (physical and mental) is presented in Table 7 The scores of the Katz scale are presented separately (including the average) and categoncally, the categories being derived from the Belgian remuneration system Mental health status is presented per item (onentation problems and restlessness)

From Table 7 it can be seen that the average rate for physical dependency is highest in Belgium, in Belgium the maximum rate (6) has the highest frequency The proportion of patients with 'low need of care (0-2)' 1s $67 \%$ (the Netherlands), $70 \%$ (Germany) and 49\% (Belgium) Mental health status is lowest in Germany and does not differ between Belgium and the Netherlands The Belgran nurses give the maximum score in a significantly higher number of cases, possible financial explanations for this phenomenon will be discussed in the discussion section The poorer mental health status in Germany cannot be explained with previous knowledge or ad hoc interpretation

\section{Provision of services}

From the factor analysis presented in Table 3, two dimensions were denved, care and cure, while injections and adminustration were considered separately As specific expectations about domestic care were formulated, this type of care should also be considered separately
The differences regarding the services provided by community nurses in the three countries are shown in Table 8 This table also includes information about the number and duration of home visits and travel time As predicted, Dutch nurses provide significantly more care than nurses in both other countries Belgian nurses record more domestic activities and German nurses record almost no administratıve duties The largest differences, however, are found in the number of injections (especially for diabetic patients) Dutch nurses record an injection in $16 \%$ of the home visits, Belgian nurses in $29 \%$ and German nurses in $45 \%$

The number and duration of the visits also differs considerably Dutch nurses (who, one should keep in mind, also provide preventive/well-baby care) have the lowest number with the longest duration (eight visits, 30 minutes), the Belgian nurses, who usually have 24-28 hour working weeks, do twice as many visits (15 to 16) with half of the duration (17 minutes), and the German nurses can be found somewhere in between (12 visits, 22 minutes) The predicted differences in travel tume (highest in Germany due to the denominational lower density of home care organizations) are confirmed Belgian nurses live very close to their clients ( $42 \%$ of the visits have only 0-2 minutes travel time compared with 15\% in Holland and $9 \%$ in Germany), they apparently do not start their work from the office but live amidst their patients

\section{Job interpretation and job satisfaction}

The factors presented in Table 4 were preventive/supportive care, domestic activities and curative/technical care Table 9 contains the differences between the three groups of nurses

No differences in job interpretation with regard to hygrenuc and technical care were found All nurses 
Table 7 Physical and mental condition of patients under treatment (KATZ

ADL + mental health assessment

Table 8 Services provided by community nurses during home visits

Table 9 Job interpretation of nurses in the three participating countries, average ratung on three dimensions

\begin{tabular}{|c|c|c|c|c|}
\hline & $\begin{array}{l}\text { Bel } \\
(n=729)\end{array}$ & $\begin{array}{l}\text { Ger } \\
(n=361)\end{array}$ & $\begin{array}{l}\text { Net } \\
(n=706)\end{array}$ & $\begin{array}{l}\text { Significant } \\
\text { differences }\end{array}$ \\
\hline \multicolumn{5}{|l|}{ KATZ ADL scale } \\
\hline Average score & 30 & 23 & 21 & Bel vs Ger, Not ** \\
\hline Standard deviation & 24 & 23 & 20 & \\
\hline Proportion 0 & 21 & 31 & 22 & Ger vs Net , Bel * \\
\hline 1 & 15 & 21 & 29 & \\
\hline 2 & 13 & 12 & 19 & \\
\hline $0-2$ & 49 & 64 & 70 & Bel vs Ger , Net * \\
\hline Proportion 3 & 10 & 3 & 4 & \\
\hline 4 & 4 & 7 & 6 & \\
\hline $3-4$ & 14 & 10 & 10 & \\
\hline Proportion 5 & 6 & 9 & 9 & \\
\hline 6 & 31 & 17 & 11 & \\
\hline $5-6$ & 37 & 26 & 20 & Bel vs Ger Net * \\
\hline \multicolumn{5}{|l|}{ Mental condition } \\
\hline \multicolumn{5}{|l|}{ Restless/nervous } \\
\hline$\%$ occasıonally & 25 & 37 & 28 & Ger vs Net, Bel * \\
\hline$\%$ permanently & 9 & 4 & 8 & \\
\hline \multicolumn{5}{|l|}{ Memory problems } \\
\hline$\%$ occasıonally & 23 & 28 & 18 & \\
\hline$\%$ permanently & 9 & 7 & 6 & \\
\hline
\end{tabular}

* Differences tested by chi-square, $P<005$

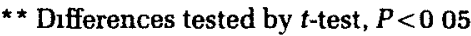

\begin{tabular}{|c|c|c|c|c|}
\hline $\begin{array}{l}\text { Av number of home visits } \\
\text { per nurse per day }\end{array}$ & 155 & 120 & 80 & \multirow{2}{*}{$\begin{array}{l}\text { Bel vs Ger vs Net * } \\
\text { Bel vs Ger vs Net * * }\end{array}$} \\
\hline $\begin{array}{l}\text { Av duration of the visit } \\
\text { (in minutes) }\end{array}$ & 175 & 224 & 290 & \\
\hline Travel time per visit (mun) & 40 & 76 & 57 & Bel vs Ger vs Net * * \\
\hline Care provided (\% visits) & 41 & 35 & 75 & Net vs Bel , Ger * \\
\hline \multicolumn{5}{|l|}{ Cure provided (\% visits) } \\
\hline Excl injections & 77 & 71 & 84 & Net vs Bel vs Ger * \\
\hline Domestic activities & 42 & 22 & 31 & Bel vs Net vs Ger * \\
\hline Injections & 29 & 45 & 16 & Ger vs Bel vs Net * \\
\hline Adminıstration ( $\%$ visits) & 33 & 4 & 33 & Ger vs Bel , Net * \\
\hline \multicolumn{5}{|c|}{$\begin{array}{l}\text { * Differences tested by chi-square, } P<005 \\
{ }^{*} \text { Differences tested by } t \text {-test, } P<005\end{array}$} \\
\hline Type of tasks & $\begin{array}{l}\text { Bel } \\
(n=30)\end{array}$ & $\begin{array}{l}\text { Ger } \\
(n=22)\end{array}$ & $\begin{array}{l}\text { Net } \\
(n=35)\end{array}$ & $\begin{array}{l}\text { Significant } \\
\text { differences* }\end{array}$ \\
\hline Preventive/supportıve tasks & 134 & 135 & 147 & Net vs Bel, Ger \\
\hline Domestıc tasks & 37 & 46 & 33 & Ger vs Net , Bel \\
\hline Hygıenıc/technıcal tasks & 59 & 58 & 59 & \\
\hline
\end{tabular}

* Differences tested by $t$-test, $P<005$ 
consider these aspects as belonging to their job Dutch nurses differ significantly from their Belgian and German colleagues in the degree they consider preventive and supportive tasks as part of their job, whlle German home nurses consider domestic tasks as part of their job significantly more often than their colleagues in the other two countries

Job satısfaction has been split into three categories organizational conditions, professional conditions and social aspects of the job In Table 10 the results per country are presented

We predicted that Dutch nurses would have the highest satısfaction rates due to their greater independence from medical supervision and the diversity of their activities The results show the opposite, Dutch nurses are the least satısfied with organizational conditions, while the Belgian nurses show the highest satısfaction with their professional conditions Satisfaction about social aspects of the job does not show differences between the countries

\section{DISCUSSION}

Returning to the initial questions of this paper, (a) can differences in community nursing between Belgium, Germany and the Netherlands with regard to patient characteristics, service provision and job interpretation and satusfaction be derived from differences in the respective health care and social security systems, and (b) will differences found in previous studies be refuted when comparable methods and research instruments are being used, we can state that the second question can be answered positively and that the answer to the first question is 'to a certain extent' The higher amount of supportive and preventive care provided by Dutch compared to Belgian nurses as found by Kerkstra \& Voskullen (1992) was confirmed in this study and was not due to differences in methods Differences in curative care turned out to stem from differences in the number of injections, especially for diabetıc patients The nurses' policy of stımulating selfcare in this respect has probably influenced this result It is not true that Dutch nurses provide less technical nursing care such as dressing wounds, preventing decubitus and applying catheters, the major source of differences is the number of injections

Regarding 'method' one element of doubt turned up with respect to the assessment of the patients' care dependency when it became clear that the Belgian nurses, who use the Katz physical condition scale to determine the per diem remuneration, had significantly more often used the maximum score of 6 However, as the remuneration cut-off point was 5 and not 6 and a confusion between the rates in the middle scores and the extreme score is not very plausible, we consider the effect of the different use of the rating scale in Belgium versus the other countries as a possible but not very probable effect and conclude that, by and large, the need of care is highest in Belgium, second in Germany and lowest in the Netherlands, the latter being as expected

The following expectations were also confirmed In the Netherlands the proportion of chents living with their children or other famly members was lower than in the other two countries This was expected, no expectations were formulated about differences between Belgium and Germany The higher travel tumes in Germany were correctly predicted, the very low travel tımes in Belgium were a surprise Belgian community nurses apparently carry out their work in an area around therr homes

Some expectations were partially confirmed It was expected that due to the differences in the requirement of medical authorization the proportion of patients referred by doctors would be highest in Germany and lowest in the Netherlands This was correct, but it was not true that the Dutch nurses had the highest number of self-referred contacts This was due to a rather large proportion of patients referred by hospitals and nursing homes, in the Netherlands $35 \%$ of the patients came from institutional care, compared with $13 \%$ in Belgium and $13 \%$ in Germany

German community nurses considered domestic tasks as part of their job significantly more often but in fact did not provide these tasks more often than the nurses in the other two countries (with the exception of preparing food and drinks) The matter of domestic tasks is apparently more complex than it seemed to be
Table 10 Job interpretation of nurses in the three participating countries, average ratung on three satisfaction dimensions

\begin{tabular}{lllll}
\hline Type of satisfaction & $\begin{array}{l}\text { Bel } \\
(n=30)\end{array}$ & $\begin{array}{l}\text { Ger } \\
(n=22)\end{array}$ & $\begin{array}{l}\text { Net } \\
(n=35)\end{array}$ & $\begin{array}{l}\text { Significant } \\
\text { differences* }\end{array}$ \\
\hline $\begin{array}{l}\text { Satisfaction with organizational } \\
\text { conditions }\end{array}$ & 234 & 234 & 210 & Net vs Bel , Ger \\
$\begin{array}{l}\text { Satısfaction with professional } \\
\text { conditions }\end{array}$ & 240 & 240 & 220 & Net vs Bel , Ger \\
$\begin{array}{l}\text { Satisfaction with social } \\
\text { aspects }\end{array}$ & 158 & 158 & 154 & \\
\hline
\end{tabular}

* Differences tested by $t$-test, $P<005$ 
Finally, the expectation that the Dutch nurses would have the highest job satisfaction was not confirmed This might have different causes Firstly, the hypothesis might be wrong, relative independence from medical supervision might increase the burden of responsibulity

Secondly, the almost permanent state of reorganization of the Dutch home care associations might be reflected in the lower rates Finally, the Dutch culture might allow more complaunts than the Belgian and German culture According to the studies of Hofstede (1984) the Dutch culture is a typical north-west European culture with feminine and egalitarian elements, while the Belgian culture forms part of the more masculıne and authoritarian Latın tradition, and Germany finds itself somewhere in between

The major conclusion, however, that can be derived from this study, is that the role of community nurses in the treatment of diabetic patients forms the most important difference between the countries This points to a more specific follow-up study in the way diabetic patients are being detected and treated by primary versus secondary nursing and medical care

\section{References}

Boerma W G W , Jong F A J M de \& Mulder P H (1993) Health Care and General Practıce Across Europe Netherlands Institute of Primary Health Care, Utrecht

Carkhuff R R (1969) Helping in Human Relations A Primer to Lay and Professional Helpers Vol 2, Practice and Research Holt, Rinehart and Winston, New York

Derksen A (1991) Thuisverpleging in de Euregıo overeenkomsten en verschillen Home nursing in the Euregion similarities and differences Masters thesis, nursing science, University of Lumburg, Maastricht

Evans R G (1981) Incomplete vertical integration the distınctive structure of the health care industry Health, Economics and Health Economics (Gaag J van der \& Perlman M eds), Elsevier, Amsterdam

Geys L \& Loon H van (1989) Deel 1 Wat voeren verpleegkundigen ut in de thusverpleging? [Part 1 What Actintses do Community Nurses Perform?] National Federation of White/Yellow Cross Associations, Brussels

Geys $\mathrm{L}$ \& Loon $\mathrm{H}$ van (1990) Deel 2 Patıüntenprofielen in de thussgezondhesdszorg [Part 2 Patient Profiles in Home Care] National Federation of White/Yellow Cross Associations, Brussels

Hofstede GH (1984) Culture's Consequences International Differences in Work-Related Values Sage, London

Katz S , Ford A B , Moskowitz R W , Jackson B A \& Faffe M W (1963) Studies of illness in the aged, the index of ADL a standardized measure of biological and psychological function Journal of the American Medical Association 914-919

Kerkstra A \& Voskuilen A (1992) Thuisverpleging in Nederland en Belgie [Home nursing in the Netherlands and Belgium ] Verpleegkunde 1, 33-45

Kerkstra A \& Vorst-Thujssen $T$ (1991) Factors related to the use of community nursing services in the Netherlends Journal of Advanced Nursing 16, 47-54

Nijkamp P , Pacolet J, Spinnewyn H, Vollering A, Wilderom C \& Winters S (1991) Services for the Elderly in Europe A crossNational Comparative Study Commission of the European Communtues, Leuven

Phılıpsen H (1985) Gezondheıd en gezondheıdszorg in Belgı̈̈ en Nederland Health and Health Care in Belgium and the Netherlands Gezondherd \& Samenleving 4, 223-231

Stevens F, Diederiks J \& Philipsen H (1992) Physıcıan satısfactıon, professional characterıstics and behaviour formalization in hospitals Social Science and Medicine 8, 295-303

Ven W P M M van de (1988) De rol van de ziektekostenverzekering In Economie van de gezondheidszorg [The role of health insurances In Economics of Health Care] (Lapre R M \& Rutten F F H eds), De Tydstroom, Lochem

Verhe1j R \& Kerkstra A (1992) International Comparatıve Study on Community Nursing Avebury, Aldershot, Hampshire

Vorst-Thyjssen T Brnk-Munnen A van de \& Kerkstra A (1990) Het werk van wijkverpleegkundigen en wikzlekenverzorgenden in Nederland [An Empirical Profile of Community Nurses and Nurses' Auxllanes in the Netherlands ] Netherlands Institute of Prumary Health Care, Utrecht

White K (1988) The Task of Medicine The Henry J Kasser Family Foundation, Menlo Park, Calıfornı 
This document is a scanned copy of a printed document. No warranty is given about the accuracy of the copy. Users should refer to the original published version of the material. 